\title{
Public Participation of Renewable Energy (PPRED) Model in Malaysia: An Instrument Development
}

\author{
W Muhammad Zainuddin B Wan Abdullaha,", Wan Nur Rahini Aznie Bt \\ Zainudin $^{\mathrm{b}}$, Waznatol Widad Bt Mohamad Ishak ${ }^{\mathrm{c}}$, Farizah Bt Sulonga, Hafiz \\ Muhammad Zia Ul Haq ${ }^{\text {a }}$
}

\author{
${ }^{a}$ Faculty of Business Economics and Social Development, Universiti Malaysia Terengganu, Malaysia \\ ${ }^{b}$ Faculty of Science and Technology, Universiti Sains Islam Malaysia, Malaysia \\ 'Institute of Energy Policy and Research, Universiti Tenaga Nasional, Malaysia
}

\begin{abstract}
Lack of an established measuring instrument for public participation towards renewable energy (RE) development has become a crucial concern for the researchers. Therefore, this research aims to develop and validate the instruments that measure public participation towards renewable energy development (PPRED) in Malaysia. This study incorporates degree of knowledge on RE (KRE), environmental concern (EC), public awareness on RE (ARE), attitude towards RE usage (AURE), and willingness to adopt RE technology (WTA) in the PPRED model, with an aim to predict public willingness to pay (WTP) for energy generated from RE sources. Using data of 172 usable responses, this study conducts an exploratory factor analysis (EFA) to analyse the factor structures. In addition to this, using data from 154 usable responses from a second sample frame, this study also conducts confirmatory factor analysis (CFA) to examine the unidimensionality of the measurement model. Correlations are used to measure discriminant and convergent validation of the items whereas Cronbach's Alpha is used to measure internal consistency among different items. Specifically, EFA is used for variable extraction and CFA is used to test dimensionality, validity, and reliability of the PPRED model. The results proved validation of the PPRED model, indicating that all instruments included are reliable and valid to be used in the research. This study is also pertinent to initiate targeted campaigns and public education policies to improve awareness among Malaysians relating to renewable energy development.
\end{abstract}

Keywords: Confirmatory Factor Analysis, Exploratory Factor Analysis, Renewable Energy, Willingness to pay

Article History: Received: $20^{\text {th }}$ August 2020; Revised: 9th October 2020; Accepted: 30 ${ }^{\text {th }}$ Oct 2020; Available online: $4^{\text {th }}$ November 2020 How to Cite This Article: Abdullah, W.M.Z.B.W., Zainudin W.N.R.A, Ishak, W.W.M., Sulong, F., Zia-Ul-Haq, H.M. (2021) Public Participation of Renewable Energy (PPRED) Model in Malaysia: An Instrument Development. Int. Journal of Renewable Energy Development, 10(1), 119-137. https://doi.org/10.14710/ijred.2021.32311

\section{Introduction}

Globalization and technological advancement have caused unexpected economic growth which has further led variations in consumption patterns of developing countries (Biswas \& Roy 2016). Due to such sudden variations in consumption patterns, unsustainable consumption behavior causes exploitation of resources. Energy as a basic necessity is an important factor for enhancing the quality of human life and/ increasing economic growth (Syed Mohamad 2016). Therefore, a country's development is usually related with its energy consumption (Mustapa, Peng, \& Hashim 2010). Considering this, renewable energy (RE) sources provide probable solution to the issue of energy overconsumption (Lim \& Lam 2014; Oladokun \& Odesola 2015). These alternative energy choices such as biomass, geothermal, solar, hydropower, and wind come in the form of energy that is environment friendly and renewable, thus cannot be consumed over time (Intergovernmental Panel on Climate Change 2011). Although Malaysia is known to have relatively high carbon dioxide emission compared to other Southeast Asian countries, however, it has taken a progressive start to reduce its carbon emission by initiating a number of carbon-mitigating projects, which promote adoption of several efficient renewable energy alternatives. In the Eleventh Malaysia Plan, the Government of Malaysia declared RE resources as the major energy source in the country. Recently in 2018, the government of Malaysia has announced to achieve target of $20 \%$ renewable energy in the mix of energy by 2025 (Abdullah et al. 2019). Economic expansion is the major goal for any country; hence it is a responsibility on the part of policymakers and environmentalists to tackle its negative effects (Adebayo, Awosusi, \& Adeshola 2020). Concerns over environmental problems and sustainable development have become major research issues and gained notable attention from researchers, academicians, industrial entities and practitioners (Irfan et al. 2020). Environmental pollution such as burning of fossil fuels to generate energy sources and exhaust fumes from vehicles

\footnotetext{
* Corresponding author: w.zainuddin@umt.edu.my
} 
are creating an alarming state for the society. Thus, the society and government need to make aggressive plans for improvement in environmental sustainability (Swan \& Ugursal 2009; Zografakis et al. 2010; Mozumder, Vásquez, \& Marathe 2011; Herbes \& Ramme 2014). Moreover, for upcoming years, usage of non-RE such as natural gas and fossil fuels focusing to generate electricity will eventually be limited. This is going to create a major issue for society since electricity is heavily dependent on it (Ashnani et al. 2014). In this regard, authorities are giving top priority to renewable energy development. Hence, renewable energy is expected to become principle source of energy in the future (Soon \& Ahmad 2015).

Hence, in order to strengthen the initiatives of promoting alternative energy resources, the Government of Malaysia in the Tenth and Eleventh Malaysia Plans, has embarked on various strategies to reduce carbon footprint in order to reaffirm their commitment to address the climate change issue.

In addition, the nation has no option but to encourage the society to accept the RE as part of diversification of fuel sources. However, the country is still facing a serious challenge on how to upsurge the contribution of RE in the mix of overall energy sources and to promote public participation towards RE development, even though it is obvious that usage of $\mathrm{RE}$ cannot be promoted without the support and participation of public.

The existing literature in Malaysia are broadly covering technological aspects of $\mathrm{RE}$ and there is a strong need to explore social aspects such as public's attitude and participation towards RE in Malaysia (Stern 1992; Stern \& Dietz 1994; Devine-Wright 2007; Said, Yahaya, \& Ahmadun 2007; Batel, Devine-Wright, \& Tangeland 2013; Alam et al. 2016). Social acceptance of RE has become a challenge for the users because of less expensive alternative sources (Alam et al. 2016). Apart from this, users' tendency to adopt new technology is also a timeconsuming process (Straub 2009). However, users' level of awareness, lifestyle, and ease of technology use are considered important factors that can influence social acceptance of RE (Faiers \& Neame 2006). The goal of RE development is hard to achieve and has become a major problem because of lesser social acceptance in the country (Wüstenhagen, Wolsink, \& Bürer 2007). Basically, advancement in $\mathrm{RE}$ development as an alternative energy source and consumption of green products depends on payment of green price premium.

The aim of this research paper is to develop and validate instruments for measuring PPRED. This study recognizes public participation as a process by which an organization includes related individuals, organizations, or government entities in its decision making. This process helps participants to express their concerns, experiences, facts, ideas, knowledge, values, preferences, and opinions. In summary, such communications and collaborative efforts can be useful in solving problems and making more effective decisions (Biswas \& Roy 2015). The PPRED model consists of multiple variables which are willingness to adopt RE technology (WTA), attitude towards RE usage (AURE), degree of knowledge on RE (KRE), public awareness on RE (ARE), and environmental concern (EC). The purpose of developing the PPRED model and including such variables is to predict WTP and examine various factors influencing WTP. Therefore, it is crucial for this study to explore socio-economic factors that can enhance RE development.
This paper is organized as follows. In the following subsection, this paper discusses the important of literature review. Whereas, materials and methods, detailed results are covered in the subsequent sections. In the last section, this paper provides concluding remarks and useful recommendations.

\section{Literature in context of Malaysia}

Malaysia has an abundant diversity of natural resources that come from both non-RE and RE. The non-RE is any source of energy that comes from natural resources but is limited, scarce and takes billions of years to be formed. For example, fossil fuels such as natural gases and coal. Such resources are known to be relatively cheap and readily available. However, heavy dependence on them could cause significant drawbacks such as carbon monoxide pollution, global warming, and climate change. On the other hand, RE can be considered as a possible alternative energy to meet the growing energy demand either locally or globally. RE is any source of energy that is produced from natural resources and can constantly be renewed and never run out. The most widely used RE technology comes from hydroelectric power, solar energy, and biomass energy. RE sources are remarkably beneficial as they produce little or no harmful waste products such as carbon dioxide, they require less maintenance and are very useful for diversification of power sources.

As an emerging nation, Malaysia has been making large investments in energy safety (Alam et al. 2016). The primary energy supply in Malaysia has risen from 0.79 ton of oil equivalent per capita in 1980 to 3.08 ton of oil equivalent per capita in 2018 (Malaysia Energy Information Hub 2020). However, the contribution of RE is very low. As most of Malaysia's economic growth depends on fossil fuel energy sources which are causing continuous rise in carbon dioxide $\left(\mathrm{CO}_{2}\right)$ emission. As a result, $\mathrm{CO}_{2}$ emissions have also increased from 2.03 metric tons per capita in 1980 to 8.1 metric tons per capita in 2016 (World Bank 2020).

\subsection{Conventional Energy Sources}

Currently, Malaysia is mainly dependent on traditional or non-renewable energy sources which include natural gas, oil, and coal (Daut et al. 2011). Out of total energy supply, $41.9 \%$ comes from only natural gas, $30 \%$ comes from crude oil and petroleum, $21.1 \%$ comes from coal, and remaining comes from all other sources (Malaysia Energy Statistics handbook 2019). Malaysia is rich in natural resources, for example the demand for natural gas in Malaysia was around 943,154 million metric standard cubic meters per day in 2015 (Abdullah et al. 2019). Coal being a cheapest fossil fuel is the major power source in peninsular Malaysia. Similarly, Malaysia as a country of 189 rivers has a high potential for hydro energy source (Tang et al. 2019). Hydro sources contribute around $13 \%$ in total power generation (Abdullah et al. 2019).

For nuclear energy source, Malaysia has a clear policy of not to include nuclear technology in the energy mix. This is mainly due to radioactive waste handling and environmental impacts (Saad et al. 2017). As Malaysia is mainly using non-renewable energy sources, hence carbon dioxide emissions are continuously rising. 


\subsection{Renewable Energy in Malaysia}

This carbon dioxide emissions contribute towards global climate change by causing more negative impacts such as health problems, destruction of nature, landscapes, biodiversity, and energy security. Under the Eighth Malaysian Plan, RE was introduced as one of the proposed energy mix in its Fuel Policy. In the past, Malaysia's former energy mix mostly relied on fossil fuels. The National Petroleum Policy guarantees optimal utilization of the oil and gas resources in order to enhance growth in the country's social, economic and environmental aspects. However, the global oil crisis of 1973 and 1978 had adversely affected the Malaysian economy due to high oil dependency in the energy mix.

Therefore, National Energy Policy of 1979 started to focus on the provision of a balanced energy mix between both fossil and renewable sources (Mannhart 2014). In existing literature (Ahmad \& Tahar 2014), it is found that $\mathrm{RE}$ resources including solar, biomass, biogas, wind and hydropower can be potential sources for developing a sustainable electricity system in Malaysia. Drawing on their analytic hierarchy process (AHP), findings revealed solar energy as the most promising $\mathrm{RE}$ resource as compared to biomass, wind, and hydropower. Hence, in the long run, RE seems to be a secure option. This is because of its distinctive features as cleaner source of energy that is inexhaustible to energy security issues.

In the last thirty years, various energy policies have been implemented by the Malaysian government (Mekhilef et al. 2011), including the Fourth and Fifth Fuel Diversification Policies, National Renewable Energy Policy and Action Plan of 2009, and the Renewable Energy Act of 2011. These policies aim, to ensure energy security, to generate energy from $\mathrm{RE}$ sources, and to improve the share of renewable sources in electricity production, respectively. Then, under the RE Act, the Feed-in-Tariff (FiT) was established to develop and implement a special tariff system with an aim to facilitate RE generation (Petinrin \& Shaaban 2015). In the Eleventh Malaysia Plan of 2015, the country aims to reduce $33 \%$ of the greenhouse gas emissions intensity of GDP and also plans to achieve $2080 \mathrm{MW}$ or $11 \%$ of the electricity production through RE sources by 2020. While at a conference of Parties in Copenhagen, Malaysia promised to decrease carbon emission to $40 \%$ by the year 2020 from the base year 2005 (COP15 2009). However, in the start of 2010, RE source constitutes only $1 \%$ of the total energy mix (Oh, Pang, \& Chua 2010; Chua, Oh, \& Goh 2011) and recently in 2018 , RE source constitutes only $2 \%$ of the total energy mix in Malaysia (Abdullah et al. 2019). This could be due to the fact that RE production is more expensive than fossil fuel energy and continuous increase in RE supply would increase the production costs for most RE sources. Hence, the global investment in $\mathrm{RE}$ technologies has increased to approximately 270 billion US\$ in 2014 with an increment of $21 \%$ from 2013 (214 billion US\$ in year 2013) (Economic Planning Unit 2015).

The Government of Malaysia is still developing aggressive renewable energy policies, as part of the commitment to promote the adoption of $\mathrm{RE}$ in the future. Recently in 2018, the government of Malaysia has announced to achieve target of $20 \%$ renewable energy in the mix of energy by 2025 (Abdullah et al. 2019). The government of Malaysia also plans to achieve $50 \%$ of this target by solar technologies. For this, Net Energy Metering program has been introduced in late 2018.
According to a report, a total 16.6 MW of Net Energy Metering has been approved in the first four months of 2019 as compared to approved capacity of $18 \mathrm{MW}$ in whole 2018 that shows a quite positive response (NEM Solar Malaysia 2020). In order to maintain this growth, the government needs to consider a raise in the electricity price by two to five percent. However, any increment in price will normally cause public objection. Therefore, the public including households and businesses have to share the RE cost burden. Currently, 1.6\% surcharges are imposed on domestic consumers who consume more than $300 \mathrm{kWh}$ of electricity per month. The revenues from this $1.6 \%$ price increase is supposed to be used in order to fund the tariff payment for production of RE under the national Feed-in Tariff (FiT) (Jacobs, 2010). Therefore, the consumption-based burden method is one of the ways for the cost to be shared, as per this method, the ones who consume more electricity need to contribute higher into the RE funds.

\subsection{Recent challenge and Literature Gap}

Based on discussed literature context in Malaysia, it implies that success of RE is very much dependent on its social acceptance among citizens of Malaysia. If public accepts and support RE usage then the government of Malaysia can easily achieve target of $20 \%$ renewable energy in the mix of energy by 2025 . Social acceptance of $\mathrm{RE}$ among public has emerged as a challenge because of less expensive alternative sources (Alam et al. 2016). In addition to this, users' behavior to adopt new technology is also a time taking phenomenon (Straub 2009). However, there several factors that can determine social acceptance of RE users include level of public awareness, lifestyle, education, and technology (Faiers \& Neame 2006). It is crucial to increase the level of public awareness and understanding in order to achieve target of RE development. (Wüstenhagen, Wolsink, \& Bürer 2007). Besides, RE development as an alternative energy source and consumption of green products also depend on payment of green price premium. Hence, it is crucial to examine socio-economic factors that can enhance $\mathrm{RE}$ usage and development.

In terms of research gap, a list of comparatives literature on the development of RE (Table 1) shows that, the technology aspect of $\mathrm{RE}$ rather than the social aspect is strongly discussed and explored. Table 1 also summarizes the reasoning in mitigating the development of instrument related to public awareness and $\mathrm{RE}$ acceptance. It is evident that, most of the existing literature covers technological aspects of $\mathrm{RE}$ and there is a lack of proper instrument for measuring public participation towards RE development in Malaysia. This also indicates to what extent the relationship between awareness and acceptance element could assist in developing new mechanism of RE program. There is a strong need to assess social aspects such as public's attitude, acceptance, participation, and concern towards RE in Malaysia (Alam et al. 2016). Thus, in order to fill this gap, this study plans to analyze potential factors explaining public intention to pay energy generation from $\mathrm{RE}$ and public participation in RE development.

On the other hand, a number of existing studies had embarked to highlight the variables that affect the WTP level. Since RE as an alternative energy source is becoming more popular, the benefits, existence and options for adoption of this energy have gained more 
attention by the public. Moreover, literature also states that level of knowledge relating to renewable technologies differ among public (Conte \& Jacobsen 2016). Therefore, it has been identified that individuals who are more aware and acknowledge these different kinds of energy resources, could increase their understanding and WTP levels on energy generated from RE sources (Al-Mulali et al. 2013). Furthermore, attitude is also known as one of the crucial predictors of actions and behavioral intentions. For example, people who have more awareness regarding the consequences of energy generation using non-RE, are found to be more willing to pay for $\mathrm{RE}$ as compared to those who possess lesser knowledge and understanding (Sebri \& Ben-Salha 2014). Similarly, public awareness is also found in the literature to be significantly influencing public willingness to use renewable energy (Makki \& Mosly 2020). In addition to this, literature also indicates education, government support, and energy subsidies as vital factors affecting public willingness to pay for renewable energy development (Ntanos et al. 2018).

Insufficient establishment of instruments for measuring public participation towards $\mathrm{RE}$ development is most probably a major gap found in the research relating to the improvement of $\mathrm{RE}$ development. In particular, measuring public awareness relating to RE, various instruments have been developed to gauge public awareness in the energy industry, but so far there is a lack of specific instruments to obtain public opinion regarding PPRED in Malaysia. Thus, for this study, several previous studies have been referred to construct the questionnaire in order to develop an instrument for PPRED model (Bang et al. 2000; Scottish Executive 2003; Curry 2004; Morgil et al. 2006; Aini \& Goh Mang Ling 2013; Salleh 2015; Kardooni, Yusoff \& Kari 2016).

\section{Materials and Methods}

\subsection{Questionnaire Development}

Employing the methodology depicted in Figure 1, this study began with a rigorous and extensive study of the literature, and subsequently a framework with six variables, where the first is dependent variable Public willingness to pay on RE (WTP) and the remaining five variables are independent. The five independent variables are Awareness on RE (ARE), Knowledge on RE (KRE), Willingness to adopt RE technology (WTA), Environmental concern (EC), and Attitude towards RE usage (AURE). The list of these variables is in Table 2 and subsequently also has developed all the items for each of the variable.

Table 1

Comparative Literature on Public Awareness and Acceptance toward RE.

Reference

Deliberation
Instrument

\section{Awareness Acceptance}

Malaysia broadly cover technological aspects of RE and there is a strong need to explore social aspects such as public's attitude and participation towards RE in Malaysia.

Individuals who are more aware on different kinds of energy resources,

(Al-Mulali 2013). from RE sources.

(Sebri and Ben-Salha 2014).

People who have more awareness regarding the consequences of energy generation using non-RE, are found to be more willing to pay for $\mathrm{RE}$ as compared to those who possess lesser knowledge and understanding.

Due to lack of awareness and knowledge about RE initiative among Malaysian, this study explores the public opinion through survey

Kardooni et al. (2018). regarding climate change and renewable energy. The election of other dependent variables like behavioral intention could be another pathway for further research.

To develop new energy program and successfully market the RE despite

(Bang et al, 2000) of environment concern, theory of reasoned action assist in examine the relationship between consumer awareness and willingness to accept by paying more in U.S.

(Aini and Ling, 2013)

Psycho-social factors including awareness variable has an affect towards the acceptance in term of willingness to pay for RE.

In Turkey, a study to develop RE awareness scale pointed out that

(Morgil et al., 2006)

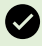
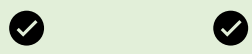

$\bullet$

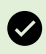

$\vartheta$

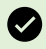

$\bullet$

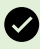

$\odot$

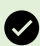
sustainable and RE. 


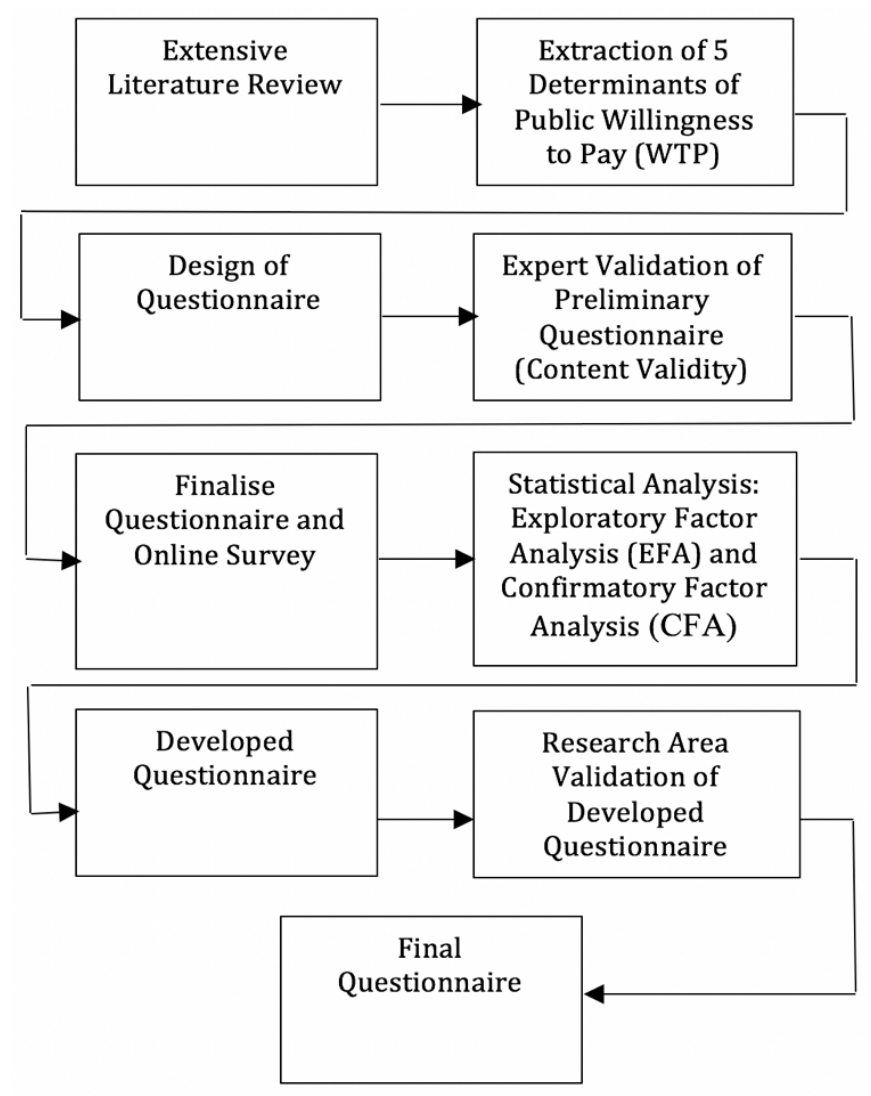

Fig. 1 Methodology Diagram

Table 2

List of Variables of PPRED

\begin{tabular}{|c|c|c|c|}
\hline Variable & Notation & $\begin{array}{l}\text { Recorded Scale } \\
\text { Dependent Variable }\end{array}$ & Reference \\
\hline $\begin{array}{l}\text { Willingness to } \\
\text { pay (WTP) }\end{array}$ & WTP & $\begin{array}{l}\text { 5- point Likert Scale type, where } 1 \text { indicates } \\
\text { "definitely not willing to pay" and } 5 \text { indicates } \\
\text { "definitely willing to pay". }\end{array}$ & $\begin{array}{l}\text { Bang et al. 2000; Aini and Goh Mang ling } \\
\text { 2013; Abdullah, Zainudin, and Ishak 2018b }\end{array}$ \\
\hline $\begin{array}{l}\text { Awareness on RE } \\
\text { (ARE) }\end{array}$ & $\mathrm{ARE}$ & $\begin{array}{l}\text { Independent Variables } \\
\text { 5- point Likert Scale response format, where } 1 \\
\text { represents "very disagree" and } 5 \text { represents } \\
\text { "very agree". }\end{array}$ & $\begin{array}{l}\text { Morgil et al. 2006; Abdullah, Zainudin, and } \\
\text { Ishak 2018b }\end{array}$ \\
\hline $\begin{array}{l}\text { Knowledge on RE } \\
\text { (KRE) }\end{array}$ & KRE & $\begin{array}{l}\text { 5- point Likert Scale response format, where } 1 \\
\text { represents "very disagree" and } 5 \text { represents } \\
\text { "very agree". }\end{array}$ & $\begin{array}{l}\text { Scottish Executive 2003; } \\
\text { Kardooni, Yusoff, and Kari 2015; Abdullah, } \\
\text { Zainudin, and Ishak 2018b }\end{array}$ \\
\hline $\begin{array}{l}\text { Willingness to } \\
\text { adopt RET (WTA) }\end{array}$ & WTA & $\begin{array}{l}\text { 5- point Likert Scale type, where } 1 \text { indicates } \\
\text { "definitely not willing to use" and } 5 \text { indicates } \\
\text { "definitely willing to use". }\end{array}$ & $\begin{array}{l}\text { Curry 2004; Abdullah, Zainudin, and Ishak } \\
2018 \text { b }\end{array}$ \\
\hline $\begin{array}{l}\text { Environmental } \\
\text { Concern (EC) }\end{array}$ & $\mathrm{EC}$ & $\begin{array}{l}\text { 5- point Likert Scale response format, where } 1 \\
\text { represents "very disagree" and } 5 \text { represents } \\
\text { "very agree". }\end{array}$ & $\begin{array}{l}\text { Salleh 2015; Abdullah, Zainudin, and Ishak } \\
\text { 2018b }\end{array}$ \\
\hline $\begin{array}{l}\text { Attitude towards } \\
\text { RE usage (AURE) }\end{array}$ & AURE & $\begin{array}{l}\text { 5- point Likert Scale response format, where } 1 \\
\text { represents "very disagree" and } 5 \text { represents } \\
\text { "very agree". }\end{array}$ & $\begin{array}{l}\text { Salleh 2015; Abdullah, Zainudin, and Ishak } \\
\text { 2018b }\end{array}$ \\
\hline
\end{tabular}

Following the framework construction, the instrument, which is in the form of a questionnaire, was designed by developing all the items for each variable. An adopt (i.e. maintain original items) and adapt (i.e. adjust the original items) approach was used to create all the items from the literature. In order to create a good and balanced questionnaire, this paper takes into consideration several requirements which are no bias (race or group), no redundant statement or double barrel, and ideal answering time (appropriate length of the questionnaire). At this stage, 62 items have been developed for the initial draft of the questionnaire which was derived from various research papers and team members' discussion groups (refer to Supplement-I). 
Table 3

Variable Research Area

\begin{tabular}{ll}
\hline Variable & Research Area \\
\hline Willingness to pay (WTP) & $\begin{array}{l}\text { Government Policies } \\
\text { and cost of RE }\end{array}$ \\
Awareness on RE (ARE) & $\begin{array}{l}\text { Community and } \\
\text { Business Participation }\end{array}$ \\
Knowledge on RE (KRE) & RE Type Sources \\
Willingness to adopt RET (WTA) & Technology \\
$\begin{array}{l}\text { Environmental Concern (EC) } \\
\begin{array}{l}\text { Attitude towards RE usage } \\
\text { (AURE) }\end{array}\end{array}$ & Environment \\
\hline
\end{tabular}

In the next step, industry experts have been consulted regarding possible areas to be covered for variables and to determine how many items to be sufficiently developed for each of the variables. Recommended research areas by an industry expert to be covered were namely, government policies, technology, environment, community and business participation, educations, cost of $\mathrm{RE}$, and $\mathrm{RE}$ type sources (refer Table 3). All variables and items involved in this study have been developed to cover all those research areas based on the recommendation from the industry experts, 17 items were deleted during this stage and one new item was added to the questionnaire. Therefore, the total items left for factor analysis testing were 46 items (refer to Supplement-II).

\subsection{Respondents and Online Survey}

A quantitative research design was used using a random sampling method to collect cross-sectional data using an online questionnaire survey conducted via google form. This study selected Klang Valley, an urban residential area in Peninsular Malaysia (Selangor, Kuala Lumpur, and Negeri Sembilan), as the population frame for sample selection. This is due to easy accessibility on the population target. Besides, Klang Valley being a federal territory is home to people of diverse races that best represents the Malaysian population. Data collection was conducted by acquiring the information through emails from employees working in private and government sectors. This study determines its sample size following stable factor structure, which suggest a sample size of at least 100 to 200. Stable factor structure also suggests 2 to 1 respondent variable ratio in order to minimize standard errors of the correlations to negligible proportions (Field 2013). A systematic random sampling method is used to ensure that a certain degree of generalization can be acquired for the population (Awang 2014; Abdul Wahab et al. 2017; Abdullah, Zainuddin, and Ishak 2018c). The researcher has constructed a continuous list of 1500 population frame and then selected every 5 th item for the sample. A total of 300 respondents were selected from the first population frame, where the first sample which for EFA comprised of 172 usable responses. Since the response rate was more than $50 \%$, hence a 172 -sample size for the present study is considered sufficient for generalizability and appropriate for the application of explanatory factor analysis (EFA) (Field 2013; Abdullah, Zainuddin, and Ishak 2018c). As for the CFA analysis, a second sample of 154 usable responses were selected out of 300 respondents acquired from the second population frame. Additionally, a manual screening and filtering were conducted on the collected data to clear any unusable questionnaire scripts. The next step is conducting the factor analysis.

\subsection{Factor Analysis}

This study used the analysis technique, an important statistical tool that is commonly used for the development of scales (Williams, Onsman, \& Brown 2010). This technique has three major uses (Gorsuch 1983). Firstly it is used for reduction of large number of variables into smaller set of factors. Secondly it allows formation of model by establishing underlying relationships between measured and latent variables. Lastly, it is also used to examine validity of scale. Factor analysis has two major steps; Exploratory Factor Analysis (EFA) and Confirmatory Factor Analysis (CFA). EFA is used to uncover underlying dimensions to formulate a model from a larger set of items (Henson \& Roberts 2006), whereas, CFA is used to examine a proposed model or theory and its underlying relationships (Williams, Onsman, \& Brown 2010). Thus, this study has employed both exploratory and confirmatory methods of factor analysis.

\subsubsection{Exploratory Analysis (EFA)}

For this study EFA is specifically conducted for the purpose of developing the questionnaire to measure an underlying variable (Field, 2013). This study has performed three steps under EFA; factor suitability, factor extraction, and rotation. Factor suitability means examining the suitability of data for the factor analysis. Particularly, this study has conducted Kaiser Mayor Olkin (KMO) (Kaiser 1970) and Bartlett (Bartlett 1950) tests for factor suitability. The KMO value greater than 0.6 and significant Bartlett test $(\mathrm{p}<0.05)$ indicate factor suitability of data (Tabachnick, Fidell, \& Ullman 2007).

For factor extraction, this study has performed Principle Component Analysis (PCA), which is considered a most commonly used method of factor extraction (Williams, Onsman, \& Brown 2010). Most literatures suggest using multiple criteria for extraction of factors (Hair et al. 1995). Thus, this study uses both Kaiser's criteria (Eigen value $>1$ ) (Kaiser 1960) and Scree test (Cattell 1966) for factor extraction. Under Kaiser's criterion, the value of eigenvalue criteria is considered one of the most commonly used criteria for factor extraction which shows the amount of variance explained by each factor (Williams, Onsman, \& Brown 2010). In PCA, the best fitted line is determined by finding the largest sum squared of distance (SSD). Using Singular Value Decomposition (SVD) method, the line is scaled up into one unit. Thus, based on transformed results (new result but maintain proportion) is called loading proportion (eigenvector). In other words, the elements of the eigenvectors are the weights for each variable. The largest eigenvalue associated with each of eigenvectors provide a 
single indicator of the substantive important for each components or variable. The basic idea is to retain components or variables with relatively large eigenvalues and ignore those with relatively small eigenvalues. As recommended by Kaiser (1960), only factor with eigenvalue greater than 1 should be retained.

As for Scree Plot, the result from Kaiser's criterion is reconfirmed by plotting each eigenvalue on the y-axis against its respective component number on the $\mathrm{x}$-axis. For illustration purposes, as shown by Scree Plot in Figure 2 . The number of variables or components to be considered is done by checking the points that appeared to the left point of inflection (or better known as elbow) and not the point of the inflection itself. In this example, two points will be considered, i.e. Point 1 and Point 2 .

In addition, the number of factors to be interpreted also depends on the underlying purpose of the analysis. However, to ease the interpretation process, several scenarios here can be considered, (1) Best scenario - if value eigenvalue above one $(>1)$ shows one component and Scree Plot also show one component, the remedies definitely choose those component, (2) Mediocre scenario Eigenvalue above one $(>1)$ more than one component, whereas Scree Plot show one component, the remedies choose one component, and next, to conduct rotation process (3) Worst scenario - Eigenvalue shows more than one components, while Scree Plot also more than one component, the remedies - next step is to conduct rotation process.

After factor extraction process, this study has performed the rotation method to analyze the possibility that a variable might be related with multiple factors. Ordinarily, rotation reduces the number of complex variables and improves interpretation. The two types of rotation are extensively being used by the researcher, i.e. (1) Varimax/Orthogonal and Direct Oblimin (Coakes, Steed, \& Ong 2010). Both methods can be used to assess the components and items. But which method to use depends on underlying factors involved. The varimax or orthogonal is for uncorrelated factors, while Direct Oblimin is for correlated factors. This is an important step where the deletion process was conducted to produce final items/questions for the research instrument.

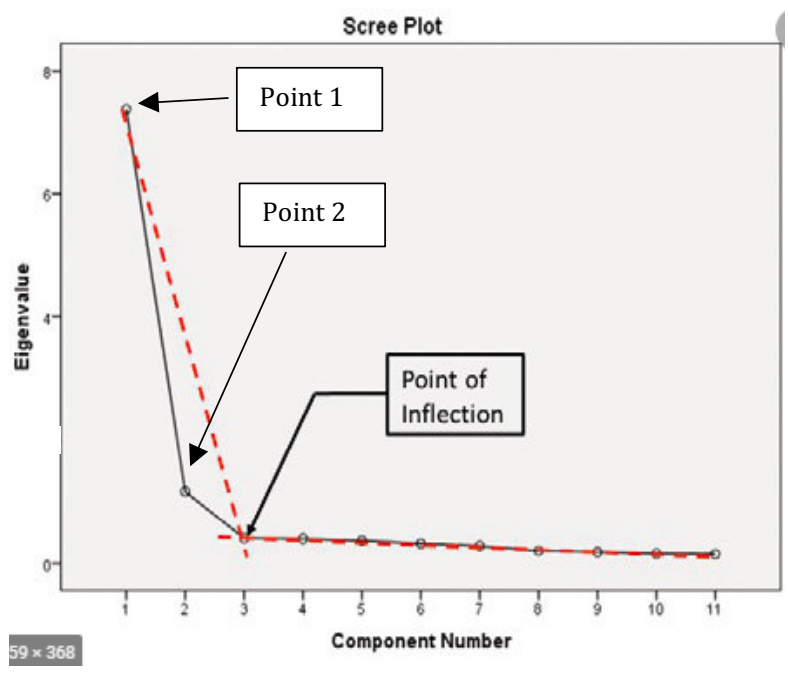

Fig. 2 Scree Plot (Developed based on Field, 2013)
For rotation process, this study used the Direct Oblimin method that produces correlated factors. Based on factor loadings from rotation process, this study considers factors/items to be retained and dropped. Under deletion and retaining process, the factor loading with 0.3 and above were retained, while the redundant (cross loading) items between components were deleted. Essentially under Direct Oblimin method, two tables have been referred, i.e. Component Matrix and Pattern Matrix (Varimax/Orthogonal - Rotated Factor Matrix Table and Factor Transformation Matrix Table). These two tables have been carefully assessed to determine which components and items to be selected. The procedures of rotation process conducted are best describe based on the following steps:

1) Choose the more interpretable table - good grouping and most items.

2) Delete redundant (cross loading) items between components.

3) Delete items with factor loading lower than 0.3.

4) Re-run the factor analysis to check the results.

5) Cross-check all items against conceptual model.

After all the factors and components achieve the required validity, final testing, i.e. reliability test has been conducted. The reliability tests are conducted to determine reliable indicators for measuring different latent variables. This test was conducted to assess the consistency between items itself (Duzan \& Shariff 2015; Ismail \& Mokhtar 2016; Abdullah, Zainudin, \& Ramli 2018a; Abdullah, Zainudin, \& Ishak 2018a). Specifically, the reliability procedures are used to check for factors reliability based on the Cronbach' Alpha value.

Three steps have been analyzed under reliability test, i.e. (1) inter-item correlation, results show that all items are in good range $(>0.3$ and $<0.9,(2)$ Standard deviation, results revealed that all items are not equal to zero $(\mathrm{SD} \neq 0)$, and finally (3), Cronbach' Alpha value, all variables are well above 0.7 . Thus, results have indicated the items reliability is achieved.

\subsubsection{Confirmatory Factor Analysis (CFA)}

The second step under factor analysis is Confirmatory Factor Analysis (CFA), which is used to test proposed relationships in the model (Stapleton 1997). This study applies CFA for construct validation and measurement evaluation. CFA is considered a necessary step in the process of scale development in order to examine latent structure of the instrument (Brown 2015). The purpose is to specify final number of factors and the pattern of indicator-factor loadings based on various parameters such as covariance of the factors and unique variances of the indicators. Pre-specified factor solution is determined on the basis of how well it reproduces covariance matrix of the measured variables in the sample. Specifically, measurement model, convergence and discriminant testing are conducted under CFA analysis (Ismail \& Mohd Mokhtar 2016; Abdullah, Zainudin, \& Ramli 2018a; Abdullah, Zainudin, \& Ishak 2018a; Abdullah, Zainudin, \& Ramli 2018b; Abdullah, Zainudin, \& Ishak 2018b; Abdullah, Zainuddin, \& Ishak 2018c; Zainuddin, Abdullah, \& Ramli 2018; Nah et al. 2019). 
Citation: Abdullah, W.M.Z.B.W., Zainudin W.N.R.A, Ishak, W.W.M., Sulong, F., Zia UI-Haq, H.M.. (2021) Public Participation of Renewable Energy (PPRED) Model in Malaysia: An Instrument Development. Int. Journal of Renewable Energy Development, 10(1),119-137, doi: 10.14710/ijred.2021.32311

P a g e $\mid 126$

Table 4

Summary Result on EFA

\begin{tabular}{|c|c|c|c|c|c|c|c|c|}
\hline \multirow[b]{2}{*}{ Variables } & \multirow[b]{2}{*}{ Constructs } & \multicolumn{2}{|c|}{ Factor Suitability } & \multicolumn{4}{|c|}{ Factor Extraction } & \multirow{2}{*}{$\begin{array}{l}\text { Rotation } \\
\text { Direct } \\
\text { Oblimin/ } \\
\text { Deleted } \\
\text { items }\end{array}$} \\
\hline & & $\begin{array}{l}\text { Bartlet } \\
\text { Test } \\
(\mathbf{p}<0.05)\end{array}$ & $\begin{array}{l}\text { Kaiser- } \\
\text { Mayer- } \\
\text { Olkin } \\
(\text { KMO> 0.6) }\end{array}$ & \multicolumn{2}{|c|}{ Eigenvalues } & $\begin{array}{c}\text { Variance } \\
\text { Explained } \\
(\%)\end{array}$ & $\begin{array}{l}\text { Scree } \\
\text { Plot }\end{array}$ & \\
\hline \multirow{13}{*}{$\begin{array}{l}\text { Dependent } \\
\text { Variable } \\
\text { Independent } \\
\text { Variables }\end{array}$} & \multirow{2}{*}{$\begin{array}{c}\text { Willingness to } \\
\text { pay (WTP) }\end{array}$} & \multirow[t]{2}{*}{.000} & \multirow[t]{2}{*}{0.884} & Factor 1 & 5.500 & 55.001 & Two & \multirow{2}{*}{$\begin{array}{l}\text { Item } 1,2,7,8 \\
\& 9\end{array}$} \\
\hline & & & & Factor 2 & 1.301 & 13.005 & Factors & \\
\hline & \multirow{2}{*}{$\begin{array}{c}\text { Awareness on } \\
\text { RE (ARE) }\end{array}$} & \multirow[t]{2}{*}{.000} & \multirow[t]{2}{*}{0.903} & Factor 1 & 6.963 & 53.561 & Two & \multirow{2}{*}{$\begin{array}{l}\text { Item } 1,3,5,6 \\
7 \& 9\end{array}$} \\
\hline & & & & Factor 2 & 1.523 & 11.713 & Factors & \\
\hline & \multirow{3}{*}{$\begin{array}{c}\text { Knowledge on } \\
\text { RE (KRE) }\end{array}$} & \multirow[t]{3}{*}{.000} & \multirow[t]{3}{*}{0.723} & Factor 1 & 3.699 & 36.986 & Three & \multirow{3}{*}{$\begin{array}{l}\text { Item } 1,2,3,4 \\
\& 5\end{array}$} \\
\hline & & & & Factor 2 & 1.838 & 18.377 & Factors & \\
\hline & & & & Factor 3 & 1.274 & 12.743 & & \\
\hline & $\begin{array}{l}\text { Willingness to } \\
\text { adopt RET } \\
\text { (WTA) }\end{array}$ & .000 & 0.864 & Factor 2 & 1.411 & 15.679 & Factors & Item $6,7 \& 8$ \\
\hline & \multirow{2}{*}{$\begin{array}{c}\text { Environmental } \\
\text { Concern (EC) }\end{array}$} & \multirow[t]{2}{*}{.000} & \multirow[t]{2}{*}{0.903} & Factor 1 & 3.671 & 57.025 & Two & \multirow{2}{*}{$\begin{array}{l}\text { Item } 3,4,6,8 \text {, } \\
\& 9\end{array}$} \\
\hline & & & & Factor 2 & 1.235 & 14.265 & Factors & \\
\hline & \multirow{3}{*}{$\begin{array}{c}\text { Attitude } \\
\text { towards RE } \\
\text { usage (AURE) }\end{array}$} & \multirow[t]{3}{*}{.000} & \multirow[t]{3}{*}{0.789} & Factor 1 & 3.617 & 40.193 & Two & \multirow{3}{*}{$\begin{array}{l}\text { Item } 1,2,8 \& \\
9\end{array}$} \\
\hline & & & & Factor 2 & 1.234 & 13.716 & Factors & \\
\hline & & & & & & & & \\
\hline
\end{tabular}

Specifically, measurement model is analysed to examine relationships between items and latent variables with aim to specify number of factors and their nature that cause variation within a set of items (Brown 2015). Further, convergent and discriminant validities are also tested for construct validation. Convergent validity refers to the evidence that various items of the same construct are strongly related to each other (Awang 2014). This study has used Average Variance Extracted (AVE) criteria to check convergent validity, which indicates establishment of convergent validity if AVE is greater than 0.5 (Scottish Executive 2003; Zainuddin, Abdullah, \& Ramli 2018).

Similarly, discriminant validity is also tested in this study which indicates that items of dissimilar constructs are not related with each other (Brown 2015). It means discriminant validity is achieved when there are no redundant items in the measurement model (Kardooni, Yusoff \& Kari 2016). Discriminant validity is tested by comparing Average Variance Extracted (AVE) and shared variance estimated (SVE). For this criterion, discriminant validity is established when AVE exceeds the SVE or another requirement for discriminant validity the correlation between exogenous constructs should be less than 0.85 (Awang, 2014; Zainuddin, Abdullah, \& Ramli 2018). Under CFA test, the system also simultaneously conducts reliability test of the construct. The purpose is to test internal consistency of the items or indicators after CFA operation being conducted. The cut-off point of Cronbach's Alpha for this purpose is also 0.70.

\section{Results}

\subsection{Factor Analysis}

Two steps of factor analysis involved, i.e. (1) Exploratory Factor Analysis (EFA), and (2) Confirmatory Factor Analysis (CFA). Those results are as follows:

\subsubsection{Exploratory Factor Analysis (EFA)}

Under the instrument development phase, exploratory factor analysis is used to determine which variable is measured by which group of questions or in other words, whether the group of items precisely measure those particular variables. All discussions for EFA results below is based on Table 4, unless stated otherwise. Steps involved in EFA are as follows:

\subsubsection{Factor Suitability, Factor Extraction, and Rotation}

The test of Kaiser-Mayer-Olkin (KMO>.60) and Bartlett Test $(p<.000)$ for all variables were conducted by applying Principle Components Analysis (PCA) to examine the factor structure of the 46 items of PPRED model included in this study. Based on the results obtained (KMO $>0.6$ and Bartlett test is significant with $\mathrm{p}<0.05$ ) for all variables, thus, all variables are suitable to proceed with EFA testing.

While, under factor extraction, results of Kaiser's Criterion show that Eigenvalue above one, produces several components for each variable and only major components were included in analysis. The component under Willingness to Pay is with two factors, Awareness on RE is with two factors, Knowledge on RE is with three factors, Willingness to Adopt is with two factors, Environmental Concern is with two factors and Attitude towards RE Usage is with two factors, next, Scree Plot was employed to re-confirm the factors for every variable. The Scree Plot result has confirmed the results obtained on the basis of eigenvalue analysis.

Third step is to do rotation process, and all variables with more than one component have been rotated. Direct Oblimin method was used under the rotation due to underlying factors that were related. 
Table 5

Result of Eigenvalue (Before and After Deletion)

\begin{tabular}{lcccc}
\hline \multirow{2}{*}{ Variable } & \multicolumn{2}{c}{ Before item-deletion } & \multicolumn{2}{c}{ After item-deletion } \\
\cline { 2 - 5 } & $\begin{array}{c}\text { Eigen } \\
\text { value }\end{array}$ & $\begin{array}{c}\text { \% of } \\
\text { Variance } \\
\text { explained }\end{array}$ & $\begin{array}{c}\text { Eigen } \\
\text { value }\end{array}$ & $\begin{array}{c}\text { \% of } \\
\text { Variance } \\
\text { explained }\end{array}$ \\
\hline WTP & 5.5 & 55.001 & 3.961 & 66.015 \\
ARE & 1.301 & 13.005 & & \\
& 6.963 & 53.561 & 6.296 & 62.959 \\
KRE & 1.523 & 11.713 & & \\
& 3.699 & 36.986 & & \\
& 1.838 & 18.377 & 3.382 & 56.374 \\
WTA & 1.274 & 12.743 & & \\
& 4.951 & 55.009 & 4.027 & 67.115 \\
EC & 1.411 & 15.679 & & \\
& 3.671 & 57.025 & 3.502 & 57.025 \\
AURE & 1.235 & 14.265 & & \\
& 3.617 & 40.193 & 3.431 & 49.02 \\
\hline
\end{tabular}

In practice, there strong ground to believe that data involves human is mostly related with each other. Thus, Direct Oblimin method is chosen than Orthogonal Rotation. Refer methodology section for detail discussion. Results from the Pattern Matrix table show that variable of Willingness to Pay, all items were majority grouped under component one, while, second component with less items and not related (less correlated and redundant) were excluded. The same assessment method was applied for the rest of the variables. Awareness on RE, Willingness to adopt, Attitude towards RE usage and Environmental Concern obtained two components each, whereas Knowledge on RE obtained three components, thus second and third components were excluded for respective variables.

To re-check the retained components, post-hoc analysis of EFA was conducted (refer Table 5). Post EFA test produced all variables with one component and this conformed the results from earlier EFA operation.

Table 6

Summary of Reliability Statistic

\begin{tabular}{ccc}
\hline \multirow{2}{*}{ Variable } & \multicolumn{2}{c}{ After deletion Process } \\
\cline { 2 - 3 } & Number of items & Cronbach Alpha \\
\hline WTP & 5 & 0.897 \\
ARE & 7 & 0.932 \\
KRE & 5 & 0.833 \\
WTA & 6 & 0.901 \\
EC & 5 & 0.914 \\
AURE & 5 & 0.826 \\
\hline
\end{tabular}

\subsubsection{Reliability Test (Cronbach's Alpha)}

After Exploratory Factor Analysis was conducted, reliability test was also conducted next in order to determine the consistency between items or questions. The results of Cronbach's Alpha after conducting EFA show that all variables are well above 0.70 . The reliability test results after item-deletion process, show that the reliability coefficients for each of the six items of public participation of RE (PPRED) model are achieved. Refer Table 6 for detail results.

\subsubsection{Final Facture Structure of Instrument}

All the items under six variables obtained from the pattern matrix table after the rotation process were similar to the original instrument adapted from literature. Only items with factor loading more than 0.3 were retained by the researcher. The retained (final) items for different variables are as follows; Willingness to Pay with five items, Awareness on RE with seven items, Knowledge on RE with five items, Willingness to Adopt with six items, Environmental Concern with five items, and Attitude towards using RE with five items. All results conformed to six original variables obtain from literature. Refer Table 7 for detail items.

\subsubsection{Confirmatory Factor Analysis (CFA)}

In the second step of factor analysis, this study has applied Confirmatory Factor Analysis (CFA) as a multivariate technique to examine factor structures of related observed variables. The purpose is to test the developed relationship between observed variables and their underlying latent constructs. In other words, it is conducted to test whether the measure of the construct is consistent with the nature of the construct or not (Hair et al. 2010; Abdullah, Zainuddin, \& Ishak 2018c; Zainuddin, Abdullah, \& Ramli 2018). The unidimensionality of all six constructs was tested and all items were also examined simultaneously using AMOS. Results are as follows:

\subsubsection{Measurement Model}

Figure 3 illustrates the results of model fit based on seven fitness indexes that has been obtained through several deletion processes and re-test of model fit. Results of CFA on the measurement model that consists of six variables show that all items have factor loadings greater than the standard cut-off point of 0.60 (Field 2013). Results of CFA and two further tests (convergence and Discriminant) are reported in Table 8 and 9.

\subsubsection{Convergence Validity}

Convergence validity relates to the extent to which variables are related with each other. It is usually established when items of the model are related and statistically significant (Awang 2014). 
Citation: Abdullah, W.M.Z.B.W., Zainudin W.N.R.A, Ishak, W.W.M., Sulong, F., Zia UI-Haq, H.M.. (2021) Public Participation of Renewable Energy (PPRED) Model in Malaysia: An Instrument Development. Int. Journal of Renewable Energy Development, 10(1),119-137, doi: 10.14710/ijred.2021.32311

P a g e $\mid 128$

Table 7

Factor Structure from EFA Operation

Awareness on Renewable Energy (ARE)
"I strongly support the use of renewable energy resources"
"I believe that media has a great responsibility in emphasizing the importance of using renewable energy resources"
"I believe that it is necessary to focus and create awareness on the importance of energy resources and energy saving
within educational programs"
"The expression of renewable energy makes me nervous because I am not used to it"
"Using renewable energy resources would remove the negative effects of the greenhouse gasses"
"I am not interested in whether the energy resources are renewable or not"
"Renewable energy and its resources are subjects that I have no idea about"

\section{Knowledge on Renewable Energy (KRE)}

"I think that I know about hydro-electric and the way it is used to produce electricity"

"I think that I know about natural gas and the way it is use to produce electricity"

"I think that I know about biomass and the way it is used to produce electricity"

"I think that I know about solar power and the way it is used to produce electricity"

"I think that I know about fossil fuel and the way it is use to produce electricity"

\section{Willingness to Adopt RE Technology (WTA)}

"Energy efficient (EE) appliances: Producing appliances that use less energy to accomplish the same tasks"

"Solar energy: Using the energy from the sun for heating or electricity production. E.g: Solar Panel"

"Energy efficient cars: Producing cars that use less energy to drive the same distance. E.g: Hybrid and solar car"

"Carbon sequestration: Using trees to absorb carbon dioxide from the atmosphere"

"Wind energy: Producing electricity from the wind, traditionally in a windmill"

"Bio-energy/biomass: Producing energy from trees or agricultural wastes such as paddy and palm trees residue"

\section{Environmental Concern (EC)}

"If things continue on their current situation, we will soon experience a major environmental disaster"

"By choosing environmentally friendly products, I signal to manufacturers the types of products they should be producing"

"When it comes to purchasing products, I consider how my use of them will affect the environment"

"The most effective way to overcome global climate change is reduce energy consumption"

"We are consuming energy much more than what we really need"

\section{Attitude towards RE Usage (AURE)}

"Appearance of renewable energy products such as solar panel is acceptable"

"Installation of renewable energy product such as solar panel is added value to the house"

"Installation of renewable energy such as solar panel is compatible with modern living style"

"Renewable energy products are safer than existing energy system"

"Renewable energy can contribute to conservation of energy"

\section{Willingness to Pay (WTP)}

"To pay $10 \%$ more in your monthly electric bill for renewable"

"To pay more now in exchange for possibly lower electric rates in the future"

"To pay more for your electric bill if you knew the cost paid for environmentally safe electricity"

"To support a fuel adjustment clause in your electric bill to subsidize the cost of developing RE-powered energy"

“To support the government's policy if the government makes a policy to generate 10\% of your electricity supply from renewable energy" 


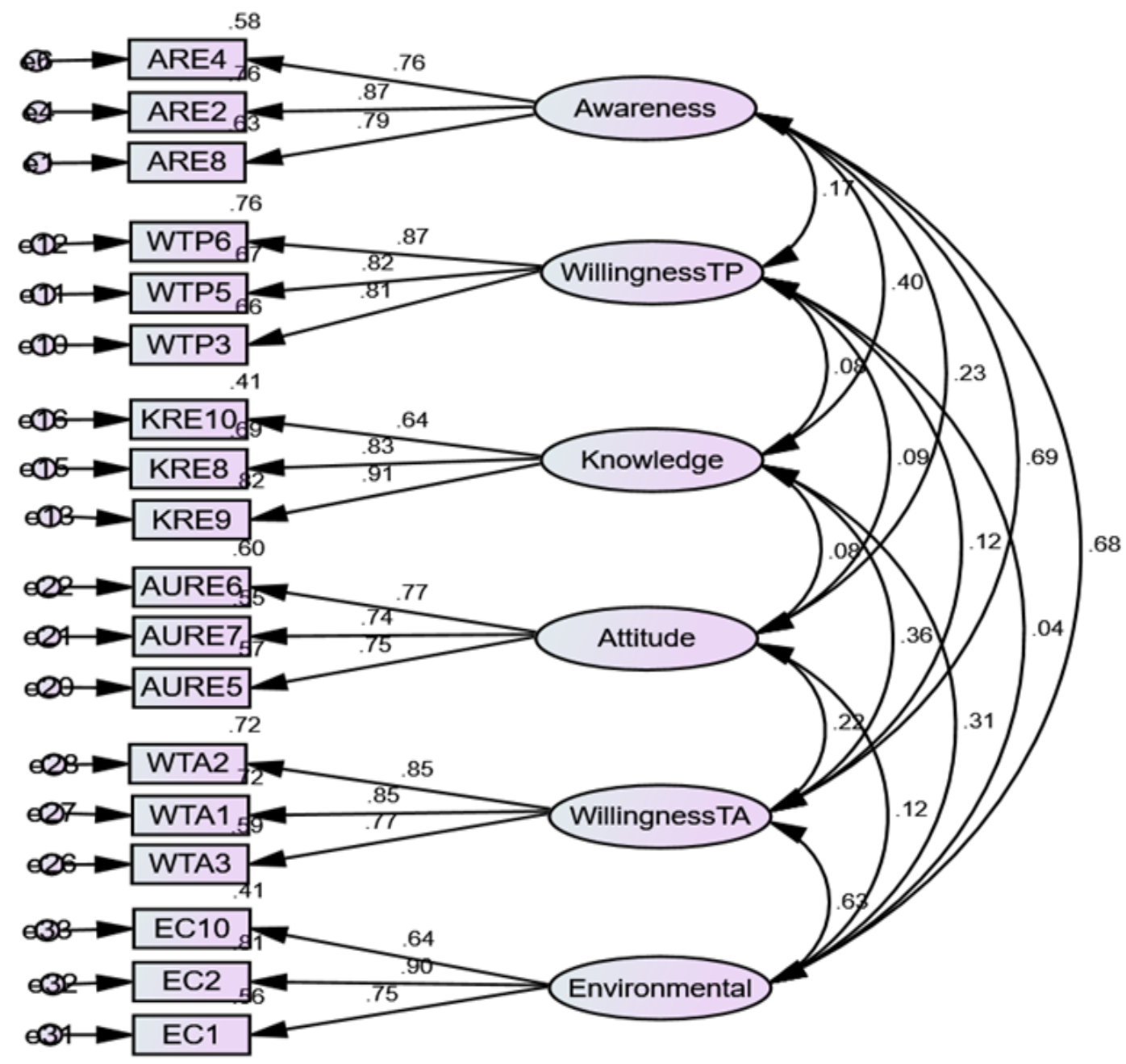

Fig. 3 CFA result of measurement model on PPRED 
Citation: Abdullah, W.M.Z.B.W., Zainudin W.N.R.A, Ishak, W.W.M., Sulong, F., Zia UI-Haq, H.M.. (2021) Public Participation of Renewable Energy (PPRED) Model in Malaysia: An Instrument Development. Int. Journal of Renewable Energy Development, 10(1),119-137, doi: 10.14710/ijred.2021.32311

P a g e $\mid 130$

Table 8

Summary Result of CFA of Measurement Model on PPRED

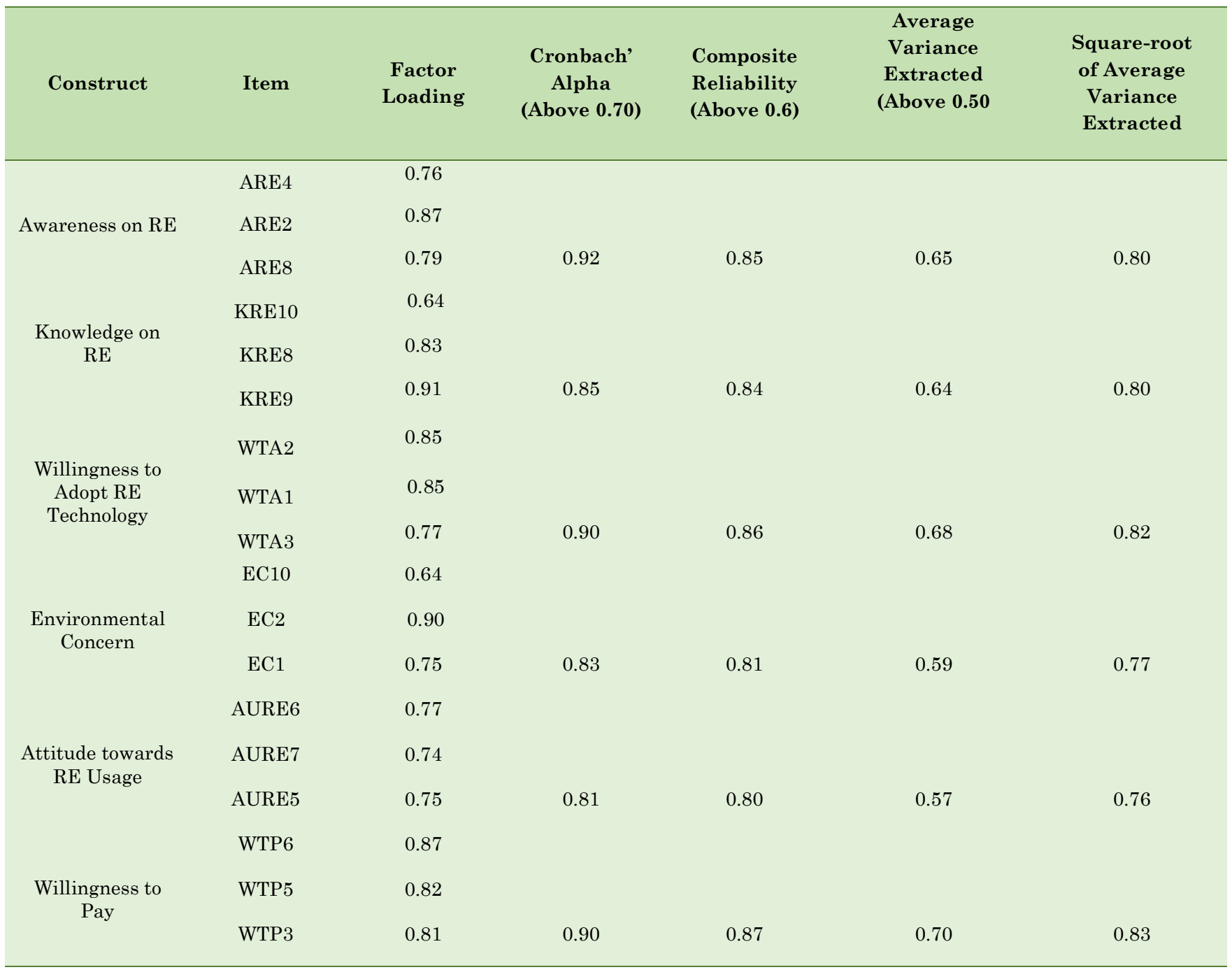

Note: Formula of Composite Reliability $\mathrm{CR}=(\Sigma \lambda)^{2} /\left[\Sigma(\lambda)^{2}+\left(\Sigma 1-\lambda^{2}\right]\right.$ (Where, $\lambda$ is factor loading), while, formula for Average Variance Extracted $(\mathrm{AVE})=\Sigma(\lambda)^{2} / \mathrm{n}$ (Where, $\lambda$ is factor loading, $\mathrm{n}=$ number of items in a model).

Table 9

The Discriminant Validity Index Summary of PPRED model

\begin{tabular}{|c|c|c|c|c|c|c|}
\hline Construct & 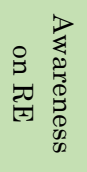 & 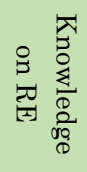 & 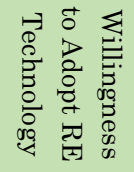 & 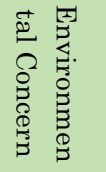 & 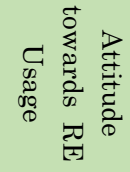 & 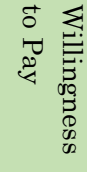 \\
\hline Awareness on RE & 0.80 & & & & & \\
\hline Knowledge on RE & 0.40 & 0.80 & & & & \\
\hline Willingness to Adopt RE Technology & 0.69 & 0.36 & 0.82 & & & \\
\hline Environmental Concern & 0.68 & 0.31 & 0.63 & 0.77 & & \\
\hline Attitude towards RE Usage & 0.23 & 0.08 & 0.22 & 0.12 & 0.75 & \\
\hline Willingness to Pay & 0.17 & 0.08 & 0.12 & 0.04 & .09 & .84 \\
\hline
\end{tabular}


Under this technique, convergence validity status can be checked by referring to Average Variance Extracted (AVE) values (Hair et al. 2010; Fornell \& Larcker 1981; Zainuddin, Abdullah, \& Ramli 2018). If value of AVE is greater than 0.5 , it shows convergent validity of the constructs is established (Scottish Executive 2003; Zainuddin, Abdullah, \& Ramli 2018). On the other hand, if AVE is less than 0.50 , it indicates that variance explained by construct is smaller than the variance explained by measurement error. Results of the convergence validity reported in Table 8 show that all variables have AVE value greater than 0.5. Thus, convergence validity for all variables were achieved.

\subsubsection{Discriminant Validity}

Discriminant validity is another subtype of construct validity, which is established when there are no redundant items in the measurement model (Aini \& Goh Mang Ling 2013; Kardooni, Yusoff \& Kari 2016; Zainuddin, Abdullah, \& Ramli 2018). AMOS identifies which of the pair item is redundant in the system in terms of high Modification Indices (MI). Discriminant validity can be achieved when Average Variance Extracted (AVE) exceeds the shared variance estimated (square of correlation). Table 9 shows that all variables have achieved the discriminant validity as the values of square root AVE (diagonal value in bold) are higher than the values in the row and column, and also the correlation between exogenous constructs is less than 0.85 . Specifically, results show that all latent variables, WTP, ARE, KRE, WTA, EC, and AURE in the measurement model are different from each other or in other words all latent variables can be discriminated against each other. Thus, discriminant validity for all variables were achieved. Meanwhile, under the reliability test, the result of Cronbach's Alpha for all variables show that values are greater than 0.70 , and composite reliability as all values exceed cut off point which is 0.60 (see Table 8).

\subsubsection{Final Factor Structure of PPRED}

Based on the results in Table 8 and Figure 3, eventually, after CFA test have been conducted, 18 final items were retained. Refer to summary Table 10.

\subsection{Results Discussion}

The major objective of this research is to construct a new measuring tool for PPRED in Malaysia. In this regard, the paper intends to develop and validate the factor structure and dimensionality of the instruments in Public Participation towards Renewable Energy Development (PPRED) model. Hence, the development of instruments has followed standard procedures including an extensive literature review of existing questionnaires and further statistical testing using available statistical tools. This process particularly involved Exploratory Factor Analysis (EFA) and Confirmatory Factor Analysis (CFA).

Based on extensive literature review, various items were gathered to assess instruments in the PPRED model. A total of sixty two (62) of identified items that were gathered from literature are as follows; ten items for Willingness to Pay, fourteen items for Awareness on RE, ten items for Knowledge on RE, nine items for Willingness to Adopt, ten items for Environmental Concern, and nine items for Attitude towards RE Usage. All items were gathered from literature and it has been studied thoroughly whereby every item were adopted/adapted according to aims of the study. Thorough test under pilot study have been carried out. In terms of content validity, several industry experts have been sought their opinion regarding the items suitability. Likewise, this study has performed complete EFA and CFA tests.

Under factor analysis, EFA is performed to examine the factor structure of a total forty six (46) items included in PPRED model. The EFA is used to extract items which precisely measure particular variables. Specifically factor suitability, factor extraction, and rotation is performed in EFA. First of all, factor suitability is conducted using Kaiser-Mayer-Olkin and Bartlett tests by applying Principle Component Analysis (PCA) on all the included items of PPRED model. Then, under factor extraction, based on the results of Kaiser's Criterion, only major components of all variables are included. Next, using direct oblimin method, rotation is performed on all the variables with more than one component. Results show that Willingness to Pay, Awareness on RE, Willingness to Adopt, Environmental Concern, and Attitude towards RE Usage have two factors each whereas Knowledge on RE has three factors. Under rotation process, only items with factor loading greater than 0.3 are retained. Therefore, based on complete EFA testing, total retained items are thirty three (33), and detail are as follows; Willingness to Pay has five items, Awareness on RE has seven items, Knowledge on RE has five items, Willingness to Adopt has six items, Environmental Concern has five items and Attitude towards RE Usage has five items. Based on criteria discussed above, final items produced under EFA operations are really measured respective variables of PPRED model. Likewise, reliability test has been conducted as final step under EFA procedure, with the aim to determine the consistency between items or questions. The results of Cronbach's Alpha after conducting EFA show that all variables value are well above 0.70 which indicate the required consistency between item is achieved.

Second step under factor analysis is CFA, whereby this CFA is applied to test the developed relationship between observed variables and their underlying latent constructs. Specifically, measurement model, convergence, and discriminant testing are performed under CFA analysis. Results on measurement model as illustrated in Figure 3, show that all factor loadings for each item are above 0.60 and the appropriate level of fitness indexes were also achieved. In addition, it shows that the underlying factor structure of PPRED model is similar to the original instruments. Results on convergence validity show that all six constructs have AVE value greater than 0.5, thus indicating that convergence validity of all variables is also achieved. Meanwhile, for discriminant validity, results from this study indicate that square root of AVE for all six constructs were greater than shared variance (Tabachnick, Fidell, \& Ullman 2007), implying that there is a significant difference between each latent variable in the model, thus achieving discriminant validity. The study also re-checked internal consistency of these six variables based on Cronbach's Alpha. The results show that all variables have acceptable value which is above 0.70 , thus 
indicating composite reliability as all values are greater than 0.60 which is considered the threshold point. As such, final remaining items after CFA testing are eighteen items (18).

Thus far, from a statistical perspective, results from EFA and CFA operations have shown that the questionnaire is reliable and valid as an instrument. Moreover, this questionnaire was also developed by consulting industry experts. Nevertheless, to give further confidence for future use, a final analysis on the remaining eighteen (18) items were performed. These variables and remaining items from EFA and CFA operations were cross-checked with research areas proposed by industry experts, and the representation of these items were further assessed via a Strength, Weakness, Opportunity and Threats (SWOT) analysis.

Table 10

Factor Structure from CFA Operation

\section{Awareness on Renewable Energy (ARE)}

Factor Loading

"I strongly support the use of renewable energy resources"

"I believe that media has a great responsibility in emphasizing the importance of using renewable energy resources"

"I believe that it is necessary to focus and create awareness on the importance of energy resources and energy saving within educational programs"

\section{Knowledge on Renewable Energy (KRE)}

"I think that I know about hydro-electric and the way it is used to produce electricity"

"I think that I know about natural gas and the way it is use to produce electricity"

"I think that I know about biomass and the way it is used to produce electricity"

\section{Willingness to Adopt RE Technology (WTA)}

"Energy efficient (EE) appliances: Producing appliances that use less energy to accomplish the same tasks"

"Solar energy: Using the energy from the sun for heating or electricity production. E.g: Solar Panel"

"Energy efficient cars: Producing cars that use less energy to drive the same distance. E.g: Hybrid and solar car"

\section{Environmental Concern (EC)}

"If things continue on their current situation, we will soon experience a major environmental disaster"

"By choosing environmentally friendly products, I signal to manufacturers the types of products they should be producing"

"When it comes to purchasing products, I consider how my use of them will affect the environment"

\section{Attitude towards RE Usage (AURE)}

"Appearance of renewable energy products such as solar panel is acceptable"

"Installation of renewable energy product such as solar panel is added value to the house"

"Installation of renewable energy such as solar panel is compatible with modern living style"

\section{Willingness to Pay (WTP)}

“To pay $10 \%$ more in your monthly electric bill for renewable" 
Table 11

SWOT Analysis

\begin{tabular}{|c|c|c|c|c|}
\hline \multirow[b]{2}{*}{ Area } & \multicolumn{4}{|c|}{ SWOT Analysis } \\
\hline & Strength & Weakness & Opportunity & Threats \\
\hline $\begin{array}{l}\text { Awareness on } \\
\text { Renewable Energy } \\
\text { (ARE) }\end{array}$ & $\begin{array}{l}\text { "I strongly support the use } \\
\text { of renewable energy } \\
\text { resources" } \\
\text { "I believe that it is } \\
\text { necessary to focus and } \\
\text { create awareness on the } \\
\text { importance of energy } \\
\text { resources and energy } \\
\text { saving within educational } \\
\text { programs" }\end{array}$ & & $\begin{array}{l}\text { "I believe that media has } \\
\text { a great responsibility in } \\
\text { emphasizing the } \\
\text { importance of using } \\
\text { renewable energy } \\
\text { resources" }\end{array}$ & \\
\hline $\begin{array}{l}\text { Knowledge on } \\
\text { Renewable Energy } \\
\text { (KRE) }\end{array}$ & & $\begin{array}{l}\text { "I think that I know } \\
\text { about hydro-electric and } \\
\text { the way it is used to } \\
\text { produce electricity" }\end{array}$ & $\begin{array}{l}\text { "I think that I know } \\
\text { about biomass and the } \\
\text { way it is used to produce } \\
\text { electricity" }\end{array}$ & $\begin{array}{l}\text { "I think that I know about } \\
\text { natural gas and the way it } \\
\text { is use to produce } \\
\text { electricity" }\end{array}$ \\
\hline $\begin{array}{l}\text { Willingness to Adopt } \\
\text { RE Technology } \\
\text { (WTA) }\end{array}$ & $\begin{array}{l}\text { "Energy efficient (EE) } \\
\text { appliances: Producing } \\
\text { appliances that use less } \\
\text { energy to accomplish the } \\
\text { same tasks" }\end{array}$ & & $\begin{array}{l}\text { "Solar energy: Using the } \\
\text { energy from the sun for } \\
\text { heating or electricity } \\
\text { production. E.g: Solar } \\
\text { Panel" }\end{array}$ & \\
\hline & & & $\begin{array}{l}\text { "Energy efficient cars: } \\
\text { Producing cars that use } \\
\text { less energy to drive the } \\
\text { same distance. E.g: } \\
\text { Hybrid and solar car" }\end{array}$ & \\
\hline $\begin{array}{l}\text { Environmental } \\
\text { Concern (EC) }\end{array}$ & $\begin{array}{l}\text { "When it comes to } \\
\text { purchasing products, I } \\
\text { consider how my use of } \\
\text { them will affect the } \\
\text { environment" }\end{array}$ & & $\begin{array}{l}\text { "By choosing } \\
\text { environmentally friendly } \\
\text { products, I signal to } \\
\text { manufacturers the types } \\
\text { of products they should } \\
\text { be producing" }\end{array}$ & $\begin{array}{l}\text { "If things continue on } \\
\text { their current situation, we } \\
\text { will soon experience a } \\
\text { major environmental } \\
\text { disaster" }\end{array}$ \\
\hline $\begin{array}{l}\text { Attitude towards RE } \\
\text { Usage (AURE) }\end{array}$ & $\begin{array}{l}\text { "Appearance of renewable } \\
\text { energy products such as } \\
\text { solar panel is acceptable" }\end{array}$ & & & \\
\hline & $\begin{array}{l}\text { "Installation of renewable } \\
\text { energy product such as } \\
\text { solar panel is added value } \\
\text { to the house" } \\
\text { "Installation of renewable } \\
\text { energy such as solar panel } \\
\text { is compatible with modern } \\
\text { living style" }\end{array}$ & & & \\
\hline $\begin{array}{l}\text { Willingness to Pay } \\
\text { (WTP) }\end{array}$ & & $\begin{array}{l}\text { "To pay } 10 \% \text { more in } \\
\text { your monthly electric } \\
\text { bill for renewable" }\end{array}$ & $\begin{array}{l}\text { "To pay more now in } \\
\text { exchange for possibly } \\
\text { lower electric rates in } \\
\text { the future" } \\
\text { "To pay more for your } \\
\text { electric bill if you knew } \\
\text { the cost paid for } \\
\text { environmentally safe } \\
\text { electricity" }\end{array}$ & \\
\hline
\end{tabular}


The strength of each variable was cross-checked against the six research areas, (1) government policies, (2) technology, (3) environment, (4) community and business participation, (5) educations, cost of RE, and (6) RE type sources, as depicted earlier in Table 2 . With the remaining 18 items covering all six variables, it shows that the instrument still sufficiently covers all six possible research areas that have been mentioned earlier in methodology section. This indicates that the proposed variables and items are sufficiently constructed by addressing all research areas that need to be incorporated for the purpose developing a good questionnaire.

Subsequently, the SWOT analysis was performed on the items to assess their representation or measurement of the various elements in $\mathrm{RE}$ development. Table 11 presents the mapping of the 18 items from the questionnaire to the six variables and SWOT dimensions. When all the measured elements were discussed under SWOT analysis and the research areas, this questionnaire comprising the remaining 18 items can be considered as an effective instrument. Further elaboration on how these items address the SWOT elements is presented in the following paragraphs.

For the three items under Awareness on RE (ARE), two of them represent the strength of the RE program that garners the support from community and businesses. Meanwhile, media, which is related to the third item, also plays a great responsibility to emphasize the importance of using RE sources that shows the opportunities to create awareness using educational method in their publications.

Next, three items under Knowledge on RE (KRE) show that industry and government sectors can explore several possibilities of RE sources that can be selected. Instead of using current sources of energy (obsolete/old technology), i.e. hydro-electric, natural oil, and gas which have a bad impact (threats) on environment, interested parties could explore for instance, solar energy, biomass and so on to produce a beneficial and clean energy.

Furthermore, one item under Willingness to Adopt RE Technology (WTA) has its strength by addressing that, in order to venture into RE investment, the invented product should benefit people which in turn will spur the demand from customers, for example home appliances products that use less energy.

The other two items under WTA address the opportunities for using energy efficient cars, such as hybrid and solar cars, which can reduce the cost incurred per kilometer, and also potentially reduce household monthly electric cost, and opportunities for using solar panels to support the existing electric grid sources from electricity providers.

Another effect from RE that really concerns the public is the impact on environment. If the current state of using natural oil, gas and coal continue, it will probably prolong the bad impact to environment, for example, the pollution of carbon dioxide $\left(\mathrm{CO}_{2}\right)$ and oil spill which pollutes the sea. Under eleventh Malaysia Plan (2016-2020), Malaysia intends to reduce the Green House Gas (GHG) emission intensity of GDP by $45 \%$ by 2030 . In relation with environmental $\mathrm{RE}$ variable, the environment friendly products should be produced in order to reduce the bad impact on eco-system.

Likewise, the significant footsteps in the introduction of the RE energy is the attitude towards RE usage from public. However, this attitude is hard to be cultivated unless an effective education programs is introduced. Such education programs should effectively and clearly explain to public regarding product involved and benefit of the technology. Malaysia has among the highest potential for solar uptake as it strategically located near the equator and all year round of hot and sunny weather. Estimated potential for solar energy generation can reach approximately up to $6500 \mathrm{MW}$ (Ahmad, Kadir, and Shafie 2011). Hence, large scale solar and rooftop solar is a good choice for solar generation energy in Malaysia.

As mentioned in introduction section, with the help and incentives from government, $\mathrm{RE}$ generation in Malaysia can be improved significantly. Nonetheless, with the introduction of RE, customer will have to pay more, for example in terms of monthly electricity bill, this is one of the drawbacks (weakness) that will affect the public perception. However, there is an opportunity in future for possible lower electric rates with the introduction of Net Energy Metering (NEM) mechanism (Abdullah et al. 2019). With this new mechanism, customer with rooftop solar will enjoy better electricity savings and also promoted the green energy to the environment. Recently, Malaysia government has announced the policy on $\mathrm{RE}$ which targeted to reach $25 \%$ of RE penetration by year 2025 (Abdullah et al. 2019). Thus, coupled with effective public education programs and right government policies introduced, this RE introduction will eventually attract public understanding and acceptance.

Consequently, given all discussions regarding the variables and items above, the analysis shows that all items have addressed all elements under SWOT technique. Hence, drawing on the overall results from both EFA and CFA operations, validation from industry practitioners, and analysis conducted using SWOT analysis, it is shown that the developed PPRED instrument was effective and valid to be used for data collection in future research relating to public participation and awareness towards RE development in Malaysia.

\section{Conclusions and Recommendations}

Although several action plans and initiatives have been developed to improve RE development, in general, these are not directly linked with public participation. Hence, the major purpose of this paper is to develop and validate instruments to measure public participation towards renewable energy, using a validation study. The analysis results clustered all items in five main components, affecting the willingness to pay for renewable energy. These components of factors are, namely, awareness of $\mathrm{RE}$, knowledge on RE, willingness to adopt RE technology, environmental concern, and attitude towards RE usage. Using data from Malaysian respondents, the results show that validated instruments of PPRED model is reliable and proved valid measurements. This means reliable and valid variables are crucial in implementation and conducting this research to create greater awareness in society on the development of RE in Malaysia. However, the results obtained is limited to the Klang Valley area. Further studies can be conducted to cater for larger areas 
or other parts of Malaysia or even a cross-border study that might gain different results.

It is suggested that government of Malaysia must initiate more research projects based on the results found in this study to achieve RE usage targets. This will also precipitate RE development projects, thus, helping government of Malaysia to achieve $25 \%$ of $\mathrm{RE}$ penetration by year 2025. In summary, this study has provided sufficient preliminary conclusions on the variables that are useful in validating the constructs of the PPRED model. In particular, the awareness and knowledge of Malaysians on RE can further be improved through welltargeted campaigns and public education policies that focus on educating the young generation who seem to be interested in RE development. Other mass media channels, such as newspapers, television, and radio can be very useful to disseminate information on $\mathrm{RE}$. The other factors that can create a great influence on rapid improvement in RE development are appropriate legislation and incentives. These include incentives for purchasing RE based products such as promoting hybrid cars through tax exemption.

\section{References}

Abdul Wahab, H., Saiti, B., Rosly, S. A., \& Masih, A. M. M. (2017). Risk-taking behavior and capital adequacy in a mixed banking system: new evidence from Malaysia using dynamic OLS and two-step dynamic system GMM estimators. Emerging Markets Finance and Trade, 53(1), 180-198; doi.org/10.1080/1540496X.2016.1162151

Abdullah, W. S. W., Osman, M., Ab Kadir, M. Z. A., \& Verayiah, R. (2019). The potential and status of renewable energy development in Malaysia. Energies, 12(12), 2437; doi:10.3390/en12122437

Abdullah, W. M. Z., Zainudin, W. N. R., \& Ishak, W. W. (2018)a. A Proposed Theoretical Model to Improve Public Participation Towards Renewable Energy (RE) Development in Malaysia. Advanced Science Letters, 24(11), 8922-8925; doi.org/10.1166/asl.2018.12376

Abdullah, W. M. Z., Zainudin, W. N. R., \& Ishak, W. W. (2018)b. The Scale for Assessment of Public Participation Towards Renewable Energy (RE) Development in Malaysia: An Exploratory Factor Analysis (EFA). Advanced Science Letters, 24(12), 9384-9388; doi.org/10.1166/asl.2018.12280

Abdullah, W.M.Z, Zainuddin, W.N.R, Ishak, W.W.M. (2018)c. "The Scale Validation of Public Participation of Renewable Energy (RE) Development in Malaysia: An Exploratory Factor Analysis (EFA)," International Journal of Recent Technology and Engineering (IJRTE), ISSN: 2277-3878, Volume-7 Issue-4S2.

Abdullah, W. M. Z., Zainudin, W. N. R., \& Ramli, N. A. (2018)a. A Proposed Model to Determine Public Acceptance on Willingness to Pay Maximum Demand (MD) Charge in Malaysia. Advanced Science Letters, 24(11), 8917-8921; doi.org/10.1166/asl.2018.12375

Abdullah, W. M. Z., Zainudin, W. N. R., \& Ramli, N. A. (2018)b. An Exploratory Factor Analysis (EFA) for Developing and Validating a Scale of Public Acceptance on Willingness to Pay (PAWP) Maximum Demand (MD) Charge in Malaysia. Advanced Science Letters, 24(12), 9379-9383; doi.org/10.1166/asl.2018.12279

Adebayo, T. S., Awosusi, A. A., \& Adeshola, I. (2020). Determinants of $\mathrm{CO} 2$ Emissions in Emerging Markets: An Empirical Evidence from MINT Economies. International Journal of Renewable Energy Development, 9(3); doi.org/10.14710/ijred.2020.31321
Ahmad, S., Ab Kadir, M. Z. A., \& Shafie, S. (2011). Current perspective of the renewable energy development in Malaysia. Renewable and sustainable energy reviews, 15(2), 897-904.

Ahmad, S., \& Tahar, R. M. (2014). Selection of renewable energy sources for sustainable development of electricity generation system using analytic hierarchy process: A case of Malaysia. Renewable energy, 63, 458-466; doi.org/10.1016/j.renene.2013.10.001

Aini, M. S., \& Goh Mang Ling, M. (2013). Factors Affecting the Willingness to Pay for Renewable Energy amongst Eastern Malaysian Households: A Case Study. Pertanika Journal of Social Sciences \& Humanities, 21(1).

Alam, S. S., Nor, N. F. M., Ahmad, M., \& Hashim, N. H. N. (2016). A survey on renewable energy development in Malaysia: Current status, problems and prospects. Environmental and Climate Technologies, 17(1), 5-17; doi.org/10.1515/rtuect2016-0002

Al-Mulali, U., Fereidouni, H. G., Lee, J. Y., \& Sab, C. N. B. C. (2013). Exploring the relationship between urbanization, energy consumption, and CO2 emission in MENA countries. Renewable and Sustainable Energy Reviews, 23, 107-112; doi.org/10.1016/j.rser.2013.02.041

Ashnani, M. H. M., Johari, A., Hashim, H., \& Hasani, E. (2014). A source of renewable energy in Malaysia, why biodiesel? Renewable and Sustainable Energy Reviews, 35, 244-257; doi.org/10.1016/j.rser.2014.04.001

Awang, Z. (2014) A handbook on SEM for academicians and practitioners: the step by step practical guides for the beginners. Bandar Baru Bangi, MPWS Rich Resources.

Bang, H. K., Ellinger, A. E., Hadjimarcou, J., \& Traichal, P. A. (2000). Consumer concern, knowledge, belief, and attitude toward renewable energy: An application of the reasoned action theory. Psychology \& Marketing, 17(6), 449-468; doi.org/10.1002/(SICI)1520-6793(200006)17:6<449::AIDMAR2 $>3.0 . \mathrm{CO} ; 2-8$

Bartlett, M. S. (1950). Tests of significance in factor analysis. British journal of psychology. 1950;3 (Part II):77-85

Batel, S., Devine-Wright, P., \& Tangeland, T. (2013). Social acceptance of low carbon energy and associated infrastructures: A critical discussion. Energy Policy, 58, 1-5; doi.org/10.1016/j.enpol.2013.03.018

Biswas, A., \& Roy, M. (2015). Green products: an exploratory study on the consumer behaviour in emerging economies of the East. Journal of Cleaner Production, 87, 463-468; doi.org/10.1016/j.jclepro.2014.09.075

Biswas, A., \& Roy, M. (2016). A study of consumers' willingness to pay for green products. Journal of Advanced Management Science, 4(3); doi.org/10.12720/joams.4.3.211-215

Brown, T. A. (2015) Confirmatory factor analysis for applied research. Guilford publications.

Cattell, R. B. (1966). The scree test for the number of factors. Multivariate behavioral research, 1(2), 245-276.

Chua, S. C., Oh, T. H., \& Goh, W. W. (2011). Feed-in tariff outlook in Malaysia. Renewable and Sustainable Energy Reviews, 15(1), 705-712; doi.org/10.1016/j.rser.2010.09.009

Coakes, S., Steed, L., \& Ong, C. (2010) SPSS: analysis without anguish: version 17 for Windows Qld. John Wiley \& Sons Australia Ltd

Conte, M. N., \& Jacobsen, G. D. (2016). Explaining demand for green electricity using data from all US utilities. Energy Economics, 60, 122-130; doi.org/10.1016/j.eneco.2016.09.001

COP15. (2009) "The Fifteen Conference of Parties." United Nations Climate Change, Copenhagen.

Curry, T. E. (2004) Public awareness of carbon capture and storage: a survey of attitudes toward climate change mitigation (Doctoral dissertation, Massachusetts Institute of Technology).

Daut, I., Irwanto, M., Irwan, Y. M., Gomesh, N., \& Rosnazri, N. A. (2011, June). Potential of solar radiation and wind speed for photovoltaic and wind power hybrid generation in Perlis, Northern Malaysia. In 2011 5th International Power 
Engineering and Optimization Conference (pp. 148-153). IEEE; doi.org/10.1109/PEOCO.2011.5970439

Devine-Wright, P. (2007). Reconsidering public attitudes and public acceptance of renewable energy technologies: a critical review. School of Environment and Development, University of Manchester, Oxford Road, Manchester.

Duzan, H., \& Shariff, N. S. B. M. (2015). Ridge regression for solving the multicollinearity problem: review of methods and models. JApSc, $15(3), 392 \quad$ 404; doi.org/10.3923/jas.2015.392.404

Economic Planning Unit (EPU)( 2015) "Malaysia Well- Being Report." Kuala Lumpur, Malaysia.

Faiers, A., \& Neame, C. (2006). Consumer attitudes towards domestic solar power systems. Energy policy, 34(14), 17971806; doi.org/10.1016/j.enpol.2005.01.001

Field, A. (2013) Discovering statistics using IBM SPSS statistics. SAGE.

Fornell, C., \& Larcker, D. F. (1981). Evaluating structural equation models with unobservable variables and measurement error. Journal of marketing research, 18(1), 3950; doi.org/10.1177/002224378101800104

Gorsuch, R. L. (1983) Factor analysis Lawrence Erlbaum Associates. Hillsdale, NJ.

Hair, J. F., Black, W. C., Babin, B. J., Anderson, R. E., \& Tatham, R. L. (2010) Multivariate data analysis. 7th ed. Englewood Cliffs, NJ: Prentice Hall.

Hair, J. F., Anderson, R. E., Tatham, R. L., \& William, C. (1995) Black: Multivariate data analysis with readings. 4. Auflage, Englewood Cliffs.

Henson, R. K., \& Roberts, J. K. (2006). Use of exploratory factor analysis in published research: Common errors and some comment on improved practice. Educational and Psychological measurement, 66(3), 393-416; doi.org/10.1177/0013164405282485

Herbes, C., \& Ramme, I. (2014). Online marketing of green electricity in Germany-A content analysis of providers' websites. Energy Policy, 66, 257-266; doi.org/10.1016/j.enpol.2013.10.083

Intergovernmental Panel on Climate Change (IPCC) (2011). Summary for Policymakers. In: IPCC Special Report on Renewable Energy Sources and Climate Change Mitigation, Cambridge University Press, Cambridge, United Kingdom and New York, NY, USA

Irfan, M., Zhao, Z. Y., Li, H., \& Rehman, A. (2020). The influence of consumers' intention factors on willingness to pay for renewable energy: a structural equation modeling approach. Environmental Science and Pollution Research, 115; doi.org/10.1007/s11356-020-08592-9

Ismail, S., \& Mohd Mokhtar, S. S. (2016). Moderating role of perceived benefit on the relationship between attitude and actual purchase. International Review of Management and Marketing, 6(S7), 17-21.

Ismail, S., \& Mokhtar, S. S. M. (2016). Linking attitude to actual purchase of herbal product in Malaysia: The moderating role of perceived risk. Journal of Asian Business Strategy, 6(2), 22; doi.org/10.18488/journal.1006/2016.6.2/1006.2.22.30

Jacobs, D. (2010). Assessment of the Proposed Malaysian Feed-in Tariff in Comparison with International Best Practise. Environmental Policy Research Centre, Distinguished Visitor under the Brain Gain Malaysia program (Ministry of Science Technology and Innovation), Hosted by the Institute for Energy Policy and Research, IEPRe(UNITEN), 3-20.

Kaiser, H. F. (1970). A second generation little jiffy. Psychometrika, 35(4), 401-415.

Kaiser, H. F. (1960). The application of electronic computers to factor analysis. Educational and psychological measurement, 20(1), doi.org/10.1177/001316446002000116

Kardooni, R., Yusoff, S. B., \& Kari, F. B. (2016). Renewable energy technology acceptance in Peninsular Malaysia. Energy policy, 88, 1-10; doi.org/10.1016/j.enpol.2015.10.005
Lim, X. L., \& Lam, W. H. (2014). Public acceptance of marine renewable energy in Malaysia. Energy Policy, 65, 16-26; doi.org/10.1016/j.enpol.2013.09.053

Makki, A. A., \& Mosly, I. (2020). Factors Affecting Public Willingness to Adopt Renewable Energy Technologies: An Exploratory $\quad$ Analysis. Sustainability, 12(3), $\quad 845$; doi.org/10.3390/su12030845

Malaysia Energy Information Hub (2020) Energy Intensity per capita. Energy Commission. Retrieved from; https://meih.st.gov.my/statistics on 30 September 2020

Malaysia Energy Statistics handbook. (2019) Malaysia Energy Statistics handbook. Energy Commission. Retrieved from; https://meih.st.gov.my/documents/10620/bcce78a2-5d5449ae-b0dc-549dcacf93ae on 30 September 2020

Mannhart, M. M. T. (2014). Analysis of the Power System of Malaysia. Energy Economics and Application Engineering. Munich: Technical University of Munich.

Mekhilef, S., Saidur, R., Safari, A., \& Mustaffa, W. E. S. B. (2011). Biomass energy in Malaysia: current state and prospects. Renewable and Sustainable Energy Reviews, 15(7), 3360-3370; doi.org/10.1016/j.rser.2011.04.016

Morgil, I., Secken, N., Yucel, A. S., Ozyalcin Oskay, O., Yavuz, S., \& Ural, E. (2006). Developing a Renewable Energy Awareness Scale for Pre-Service Chemistry Teachers. Online Submission, 7(1), 63-74;

Mozumder, P., Vásquez, W. F., \& Marathe, A. (2011). Consumers' preference for renewable energy in the southwest USA. Energy economics, 33(6), 1119-1126; doi.org/10.1016/j.eneco.2011.08.003

Mustapa, S. I., Peng, L. Y., \& Hashim, A. H. (2010, June). Issues and challenges of renewable energy development: A Malaysian experience. In Proceedings of the International Conference on Energy and Sustainable Development: Issues and Strategies (ESD 2010) (pp. 1-6). IEEE; doi.org/ 10.1109/ESD.2010.5598779

Nah, N. S. M., Ismail, S., Ramayah, T., Abu Hassan, Z. R., and Hanaysha, J. R. (2019). Modelling the Use of Grabcar Ridesharing Services. International Journal of Recent Technology and Engineering, vol. 8, no. 2, pp. 2277-3878; Doi.org/10.35940/ijrte.B1055.0782S219

NEM Solar Malaysia (2020) Net Energy Metering solar Malaysia. Retrieved from; https:// http://nemsolarmalaysia.com/category/news/ on 26 October 2020

Ntanos, S., Kyriakopoulos, G., Chalikias, M., Arabatzis, G., \& Skordoulis, M. (2018). Public perceptions and willingness to pay for renewable energy: A case study from Greece. Sustainability, 10(3), $\quad 687$; doi.org/10.3390/su10030687

Oh, T. H., Pang, S. Y., \& Chua, S. C. (2010). Energy policy and alternative energy in Malaysia: issues and challenges for sustainable growth. Renewable and Sustainable Energy Reviews, 14(4), 1241-1252; doi.org/10.1016/j.rser.2009.12.003

Oladokun, M. G., \& Odesola, I. A. (2015). Household energy consumption and carbon emissions for sustainable cities-A critical review of modelling approaches. International Journal of Sustainable Built Environment, 4(2), 231-247; doi.org/10.1016/j.ijsbe.2015.07.005

Petinrin, J. O., \& Shaaban, M. (2015). Renewable energy for continuous energy sustainability in Malaysia. Renewable and Sustainable Energy Reviews, 50, 967-981; doi.org/10.1016/j.rser.2015.04.146

Saad, M. A., Ismail, F. A., Fauzi, F. M., \& Rahmat, M. K. (2017, September). Consideration for nuclear energy in Malaysia. In 2017 International Conference on Engineering Technology and Technopreneurship (ICE2T) (pp. 1-5). IEEE; doi.org/ 10.1109/ICE2T.2017.8215964

Said, A. M., Yahaya, N., \& Ahmadun, F. L. R. (2007). Environmental comprehension and participation of Malaysian secondary school students. Environmental $\begin{array}{lll}\text { education } & \text { research, } & 13(1),\end{array}$ doi.org/10.1080/13504620601122616 
Salleh, A. M. (2015) The economic valuation of solar water heating systems and the determinants of its adoption by the Libyan households.

Scottish Executive (2003) "Attitudes and Knowledge of Renewable Energy amongst the General Public." Department of Trade and Industry, August, pp. 1-9.

Sebri, M., \& Ben-Salha, O. (2014). On the causal dynamics between economic growth, renewable energy consumption, CO2 emissions and trade openness: Fresh evidence from BRICS countries. Renewable and Sustainable Energy Reviews, 39, 14-23; doi.org/10.1016/j.rser.2014.07.033

Soon, J. J., \& Ahmad, S. A. (2015). Willingly or grudgingly? A meta-analysis on the willingness-to-pay for renewable energy use. Renewable and Sustainable Energy Reviews, 44, 877887; doi.org/10.1016/j.rser.2015.01.041

Stapleton, C. D. (1997) Basic Concepts and Procedures of Confirmatory Factor Analysis; https://files.eric.ed.gov/fulltext/ED407416.pdf

Stern, P. C. (1992). Psychological dimensions of global environmental change. Annual review of psychology, 43(1), 269-302; doi.org/10.1146/annurev.ps.43.020192.001413

Stern, P. C., \& Dietz, T. (1994). The value basis of environmental concern. Journal of social issues, 50(3), 65-84; doi.org/10.1111/j.1540-4560.1994.tb02420.x

Straub, E. T. (2009). Understanding technology adoption: Theory and future directions for informal learning. Review of educational research, 79(2), 625-649; doi.org/10.3102/0034654308325896

Swan, L. G., \& Ugursal, V. I. (2009). Modeling of end-use energy consumption in the residential sector: A review of modeling techniques. Renewable and sustainable energy reviews, 13(8), 1819-1835; doi.org/10.1016/j.rser.2008.09.033
Syed Mohamad, S. F. (2016) Shariah non-compliance risks in shared and outsourced services of takaful operators with insights from maqasid al-Shariah. INCEIF, Kuala Lumpur.

Tabachnick, B. G., Fidell, L. S., \& Ullman, J. B. (2007) Using multivariate statistics (Vol. 5, pp. 481-498). Boston, MA: Pearson.

Tang, S., Chen, J., Sun, P., Li, Y., Yu, P., \& Chen, E. (2019). Current and future hydropower development in Southeast Asia countries (Malaysia, Indonesia, Thailand and Myanmar). Energy Policy, 129, 239-249; doi.org/10.1016/j.enpol.2019.02.036

Williams, B., Brown, T., \& Onsman, A. (2017). Exploratory factor analysis: a five-step guide for novices. Australas J Paramed 8 (3); doi.org/10.33151/ajp.8.3.93

World Bank Data. (2020) CO2 emissions. Retrieved from; https://ata.worldbank.org/indicator/EN.ATM.CO2E.PC?loca tions $=$ MY on 30th September 2020

Wüstenhagen, R., Wolsink, M., \& Bürer, M. J. (2007). Social acceptance of renewable energy innovation: An introduction to the concept. Energy policy, 35(5), 2683-2691; doi.org/10.1016/j.enpol.2006.12.001

Zainuddin, W.N.R, Abdullah, W.M.Z, Ramli, N.A. (2018). A Preliminary Study On Electricity Affordability and Willingness to Pay (WTP) On Maximum Demand (MD) Charge Among Residential Electricity Customers in Malaysia. International Journal of Recent Technology and Engineering (IJRTE), ISSN: 2277-3878, Volume-7 Issue-4S2.

Zografakis, N., Sifaki, E., Pagalou, M., Nikitaki, G., Psarakis, V., \& Tsagarakis, K. P. (2010). Assessment of public acceptance and willingness to pay for renewable energy sources in Crete. Renewable and sustainable energy reviews, 14(3), 1088-1095; doi.org/10.1016/j.rser.2009.11.009 